\title{
Mass Spectrometry Study of New Polyamine Derivatives of Caffeine
}

\author{
Arleta Sierakowska*, Beata Jasiewicz and Tomasz Pospieszny \\ Faculty of Chemistry, Adam Mickiewicz University in Poznań, Umultowska 89b, 61-614 Poznań, Poland. \\ ${ }^{*}$ Corresponding author: E-mail: asierak@amu.edu.pl; \\ Tel. $+4861829-1758$
}

Received: $14-03-2018$

\begin{abstract}
The mass spectrometric fragmentations of ten new 8-alkylaminocaffeine derivatives were investigated. The fragmentation pathways of new polyamine derivatives of caffeine on the basis of low and high-resolution electron ionization (EI) mass spectra were discussed. In the case of new compounds, classical fragmentation of purine skeleton related to the elimination of a neutral molecule $\mathrm{CH}_{3} \mathrm{~N}(1) \mathrm{C}(2) \mathrm{O}$ from a molecular ion was not observed. Nevertheless, new interesting fragmentation of described caffeine derivatives was observed. Moreover, heats of formation of odd-electron ions of 8 -alkylaminocaffeine derivatives were calculated.
\end{abstract}

Keywords: Caffeine; polyamine; EI-MS; semiempirical calculation.

\section{Introduction}

Alkaloids constitute a large group of naturally occurring chemical compounds with a wide range of pharmacological properties. ${ }^{1}$ They are produced by various organisms including bacteria, fungi, plants and animals. Caffeine (1,3,7-trimethylxanthine), the main representative of purine alkaloids, is a bicyclical amine. The most well-known source of this chemical compound are the seeds of coffee (especially Arabica - Coffea arabica, and Robusta - Coffea canephora) or leaves of tea. ${ }^{2}$ This alkaloid is a central nervous system (CNS) stimulant and one of the most addicting psychoactive drugs. This is the result of inhibition of adenosine A2A receptor by caffeine and its derivatives. ${ }^{3}$ Caffeine has also the anti-inflammatory capacity and enhances the glucose uptake as well as anticancer capacity and officially modulates drugs against lung, liver, uterine cervix, and breast cancer. ${ }^{4-7}$ It enhances the effect of anticancer drugs and the most important is modulation of cis-platinum efficacy induced by caffeine. ${ }^{8}$ Caffeine is also the lead compound for the development of new drugs. For example, 8-substituted caffeine derivatives are very important chemical compounds that possess pharmacological activity. This kind of derivatives inhibits the monoamine oxidases (MAO) A and B. MAO-A inhibitors can be employed as antidepressant drugs and MAO-B inhibitors can be used in Parkinson's disease therapy. ${ }^{9,10} 8$-aryl- or heteroaryl-substituted xantines are highly potent antago- nists at human adenosine receptors. ${ }^{11} 8$-[(pyrrolidin-1-ylcarbonothioyl)-sulfanyl]caffeine has exceptionally high antioxidant properties and protects human erythrocytes against AAPH-induced oxidative damage. ${ }^{12}$

According to the literature, the caffeine molecule as well as its derivatives were studied by different analytical methods. Mass spectrometry with electron ionization and chemical ionization in combination with liquid or gas chromatography was found. ${ }^{13-15}$ There are a few reports found in the literature describing advanced methods studying the caffeine molecule, e.g. photoion mass spectroscopy (PI-MS), ${ }^{16}$ thermal and hyperthermal surface ionization (HSI) mass spectrometry. ${ }^{17}$ In this work we propose the fragmentation pathways of new polyamine derivatives of caffeine on the basis of low and high-resolution EI-MS spectra. This is the new report of mass fragmentation of $\mathrm{C}(8)$ substituted derivatives of caffeine. The main goal of our study was to establish how far the presence of di- or polyamino group at C-8 position influences the pathways of fragmentation of this important class of compounds.

\section{Experimental}

Low-resolution and high-resolution mass spectra were recorded using a model 432 two-sector mass spectrometer [AMD-IntectraGmbH D-27243 Harpstedt, Ger- 
many] at ionizing energy $70 \mathrm{eV}$, accelerating voltage $8 \mathrm{kV}$, mass resolution 10000 at $10 \%$ valley. Samples were introduced by a direct insertion probe at a source temperature of $\sim 150{ }^{\circ} \mathrm{C}$. The elemental compositions of the ions were determined by peak matching method relative to perfluorokerosene. The tandem product ion mass spectra in the first field-free region were recorded using linked scans at constant $\mathrm{B} / \mathrm{E}$ with helium as collision gas at an indicated pressure of $1.75 \times 10^{-5} \mathrm{~Pa}$ with an ion source temperature of $180{ }^{\circ} \mathrm{C}$, ionizing energy of $70 \mathrm{eV}$ and an accelerating voltage of $8 \mathrm{KV}$.

\section{Results and Discussion}

All new di- or polyamine derivatives of caffeine were synthesized according to procedure described in $^{18}$ (Scheme 1) with good yields (60-90\%).

The representative samples of set of EI mass spectra of 8-(6-aminohexylamino)caffeine (5), 8-(4-(3-aminopropylamino)-butylamino)caffeine (8) and 8-(3-(3-(3-aminopropylamino)propylamino)propylamino)caffeine (9) are presented in S1. The EI-MS data of 8-(2-aminoethylamino)caffeine (1), 8-(3-aminopropylamino)caffeine (2), 8-(4-aminobutylamino)caffeine (3), 8-(5-aminopentylamino)caffeine (4) as well as 8-(6-aminohexylamino)caffeine (5) are displayed in Table 1. On the basis of low-resolution EI mass spectra, exact mass measurements and also $\mathrm{B} / \mathrm{E}$ linked scan spectra, the principal fragmentation routes of 8-(2-aminoalkylamino)caffeines 1-5 are proposed in Scheme 1. The presence of alkylamino chain in position $\mathrm{C}(8)$ of caffeine rings caused the absence of classical fragmentation related with the elimination of a neutral molecule $\mathrm{CH}_{3} \mathrm{~N}(1) \mathrm{C}(2) \mathrm{O}$ from a molecular ion.

In the EI mass spectra of 1-5, molecular ions a were observed in all derivatives and for 2, 4 and 5 its relative abundance is $100 \%$ (Scheme 1, Table 1). Furthermore, the even-electron fragment ions $\mathbf{b}_{1}, \mathbf{b}_{2}, \mathbf{b}_{3}, \mathbf{b}_{4}$ and $\mathbf{b}_{5}$ are formed from the molecular ion by the loss of $\mathrm{CH}_{2} \mathrm{NH}_{2}$ radical. The ions $\mathbf{b}_{\mathbf{3}}$ and $\mathbf{b}_{\mathbf{2}}$ are not created for derivatives
3 and 4. Elimination of alkylaminoradical chain from $\mathrm{C}(8)$ of purine ring with migration of two hydrogen atoms leads to even-electron ion $\mathbf{e}$. The simultaneous cleavages of $\mathrm{C}(5) \mathrm{sp}^{2}-\mathrm{N}(7) \mathrm{sp}^{3}$ and $\mathrm{C}(4) \mathrm{sp}^{2}-\mathrm{N}(9) \mathrm{sp}^{2}$ bonds of the skeletons of ion e of 1-5 lead to the formation of the even-electron ion i. Relative abundance for this ion for 8 -(5-aminopentylamino)caffeine (4) is $100 \%$. From this fragment ion, by elimination of the neutral molecules $\mathrm{CH}_{4}$ and $\mathrm{C}_{2} \mathrm{H}_{2}$, ions $\mathbf{j}$ and $\mathbf{k}$ are formed, respectively. The decompositions of the 1-5 molecular ions with the cleavages of $\mathrm{C}(8) \mathrm{sp}^{2}-\mathrm{Nsp}^{3}$ bond, and the next elimination of

Table 1. The EI MS data of 8-(2-aminoethylamino)caffeine (1), 8-(3-aminopropylamino)caffeine (2), 8-(4-aminobutylamino)caffeine (3), 8-(5-aminopentylamino)caffeine (4) and 8-(6-aminohexylamino)caffeine (5).

\begin{tabular}{lccccccc}
\hline Ion & $\boldsymbol{m} / \boldsymbol{z}$ & Elemental & \multicolumn{4}{c}{ \% Relative abundance } \\
& & composition & $\mathbf{1}$ & $\mathbf{2}$ & $\mathbf{3}$ & $\mathbf{4}$ & $\mathbf{5}$ \\
\hline $\mathrm{M}^{+} \mathbf{a}$ & 308 & $\mathrm{C}_{14} \mathrm{H}_{24} \mathrm{~N}_{6} \mathrm{O}_{2}$ & - & - & - & - & 100 \\
& 294 & $\mathrm{C}_{13} \mathrm{H}_{22} \mathrm{~N}_{6} \mathrm{O}_{2}$ & - & - & - & 6 & - \\
& 280 & $\mathrm{C}_{12} \mathrm{H}_{20} \mathrm{~N}_{6} \mathrm{O}_{2}$ & - & - & 100 & - & - \\
& 266 & $\mathrm{C}_{11} \mathrm{H}_{18} \mathrm{~N}_{6} \mathrm{O}_{2}$ & - & 100 & - & - & - \\
& 252 & $\mathrm{C}_{10} \mathrm{H}_{16} \mathrm{~N}_{6} \mathrm{O}_{2}$ & 50 & - & - & - & - \\
$\mathbf{b}_{\mathbf{1}}$ & 278 & $\mathrm{C}_{13} \mathrm{H}_{20} \mathrm{~N}_{5} \mathrm{O}_{2}$ & - & - & - & - & 11 \\
$\mathbf{b}_{\mathbf{2}}$ & 264 & $\mathrm{C}_{12} \mathrm{H}_{18} \mathrm{~N}_{5} \mathrm{O}_{2}$ & - & - & - & 0 & - \\
$\mathbf{b}_{3}$ & 250 & $\mathrm{C}_{11} \mathrm{H}_{16} \mathrm{~N}_{5} \mathrm{O}_{2}$ & - & - & 0 & - & - \\
$\mathbf{b}_{\mathbf{4}}$ & 236 & $\mathrm{C}_{10} \mathrm{H}_{14} \mathrm{~N}_{5} \mathrm{O}_{2}$ & - & 12 & - & - & - \\
$\mathbf{b}_{\mathbf{5}}$ & 222 & $\mathrm{C}_{9} \mathrm{H}_{12} \mathrm{~N}_{5} \mathrm{O}_{2}$ & 100 & - & - & - & - \\
$\mathbf{c}_{\mathbf{1}}$ & 278 & $\mathrm{C}_{13} \mathrm{H}_{20} \mathrm{~N}_{5} \mathrm{O}_{2}$ & - & - & - & 2 & - \\
$\mathbf{c}_{\mathbf{2}}$ & 236 & $\mathrm{C}_{10} \mathrm{H}_{14} \mathrm{~N}_{5} \mathrm{O}_{2}$ & - & - & - & 2 & - \\
$\mathbf{c}_{\mathbf{1}}$ & 236 & $\mathrm{C}_{10} \mathrm{H}_{14} \mathrm{~N}_{5} \mathrm{O}_{2}$ & 0 & 0 & 0 & - & 19 \\
$\mathbf{c}_{\mathbf{2}}$ & 222 & $\mathrm{C}_{9} \mathrm{H}_{12} \mathrm{~N}_{5} \mathrm{O}_{2}$ & 0 & 0 & 0 & - & 60 \\
$\mathbf{d}$ & 209 & $\mathrm{C}_{8} \mathrm{H}_{11} \mathrm{~N}_{5} \mathrm{O}_{2}$ & 35 & 2 & 28 & 4 & 44 \\
$\mathbf{e}$ & 195 & $\mathrm{C}_{8} \mathrm{H}_{11} \mathrm{~N}_{4} \mathrm{O}_{2}$ & 17 & 2 & 26 & 2 & 3 \\
$\mathbf{f}$ & 165 & $\mathrm{C}_{7} \mathrm{H}_{9} \mathrm{~N}_{4} \mathrm{O}$ & 20 & 5 & 0 & 3 & 4 \\
$\mathbf{g}$ & 141 & $\mathrm{C}_{6} \mathrm{H}_{9} \mathrm{~N}_{2} \mathrm{O}_{2}$ & - & 19 & - & - & - \\
$\mathbf{h}$ & 108 & $\mathrm{C}_{5} \mathrm{H}_{6} \mathrm{~N}_{3}$ & 7 & 1 & 17 & 21 & 6 \\
$\mathbf{i}$ & 83 & $\mathrm{C}_{4} \mathrm{H}_{7} \mathrm{~N}_{2}$ & 12 & 2 & 23 & 100 & 9 \\
$\mathbf{j}$ & 67 & $\mathrm{C}_{3} \mathrm{H}_{3} \mathrm{~N}_{2}$ & 40 & 4 & 87 & 63 & 24 \\
$\mathbf{k}$ & 57 & $\mathrm{C}_{2} \mathrm{H}_{5} \mathrm{~N}_{2}$ & 16 & 19 & 65 & 17 & 44 \\
\hline & & & & & &
\end{tabular}<smiles>[R]Nc1nc2c(c(=O)n(C)c(=O)n2C)n1C</smiles>

(1) $\mathrm{R}=-\left(\mathrm{CH}_{2}\right)_{2} \mathrm{NH}_{2}$

(2) $\mathrm{R}=-\left(\mathrm{CH}_{2}\right)_{3} \mathrm{NH}_{2}$

(3) $\mathrm{R}=-\left(\mathrm{CH}_{2}\right)_{4} \mathrm{NH}_{2}$

(4) $\mathrm{R}=-\left(\mathrm{CH}_{2}\right)_{5} \mathrm{NH}_{2}$

(5) $\mathrm{R}=-\left(\mathrm{CH}_{2}\right)_{6} \mathrm{NH}_{2}$

(6) $\mathrm{R}=-\left(\mathrm{CH}_{2}\right)_{2} \mathrm{NH}\left(\mathrm{CH}_{2}\right)_{2} \mathrm{NH}_{2}$

(7) $\mathrm{R}=-\left(\mathrm{CH}_{2}\right)_{3} \mathrm{NH}\left(\mathrm{CH}_{2}\right)_{3} \mathrm{NH}_{2}$

(8) $\mathrm{R}=-\left(\mathrm{CH}_{2}\right)_{4} \mathrm{NH}\left(\mathrm{CH}_{2}\right)_{3} \mathrm{NH}_{2}$

(9) $\mathrm{R}=-\left(\mathrm{CH}_{2}\right)_{3} \mathrm{NH}\left(\mathrm{CH}_{2}\right)_{3} \mathrm{NH}\left(\mathrm{CH}_{2}\right)_{3} \mathrm{NH}_{2}$

(10) $\mathrm{R}=-\left(\mathrm{CH}_{2}\right)_{3} \mathrm{NH}\left(\mathrm{CH}_{2}\right)_{4} \mathrm{NH}\left(\mathrm{CH}_{2}\right)_{3} \mathrm{NH}_{2}$

Figure 1. The synthesis of di- and polyamine derivatives of caffeine (1-10). 


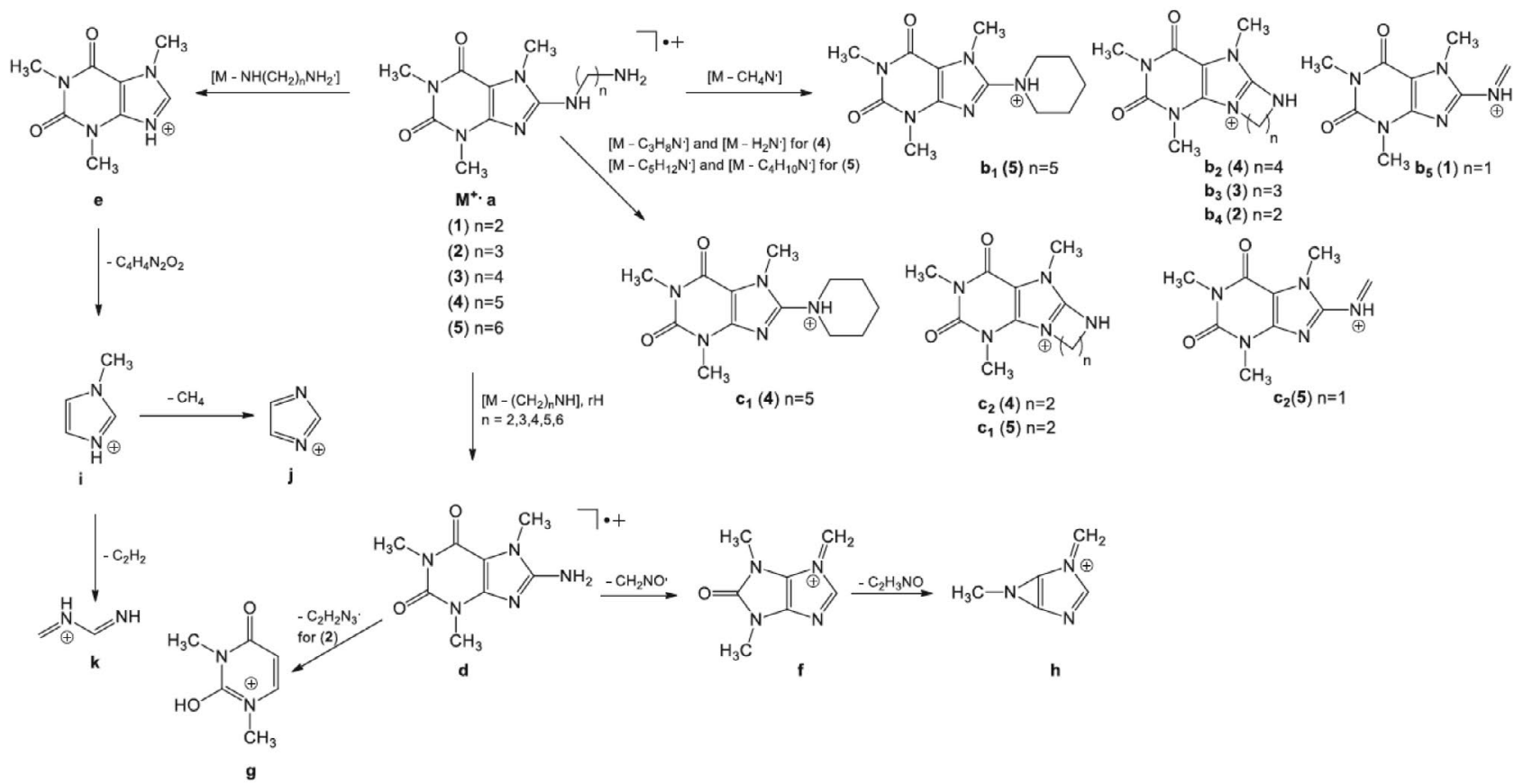

Sheme 1. The EI fragmentation pathways of compounds (1-5).

the $\mathrm{NH}_{2}\left(\mathrm{CH}_{2}\right)_{\mathrm{m}}$ radical, where $\mathrm{m}$ is $2,3,4,5$, and 6 , lead to the formation of the odd-electron ion $\mathbf{d}$. Elimination of radicals $\mathrm{C}_{2} \mathrm{H}_{2} \mathrm{~N}_{3}$ or $\mathrm{CH}_{2} \mathrm{NO}$ from ion d leads to even-electron ions $\mathbf{g}$ (only for $\mathbf{2}$ ) and $\mathbf{f}$ (for 1-5), respectively. Elimination of neutral molecule $\mathrm{C}_{2} \mathrm{H}_{3} \mathrm{NO}$ from even-electron ion $\mathbf{f}$ creates bicyclic even-electron ion $\mathbf{h}$. This bicyclic structure is one of mesomeric and more stable structures of even-electron ion $\mathbf{h}$.

The fragmentation process of the molecular ions of 4 and $\mathbf{5}$ leads to the formation of ions $\mathbf{c}$. The accurate mass measurement enables the assignment of peaks to three even-electron ions. They are formed directly from the re-

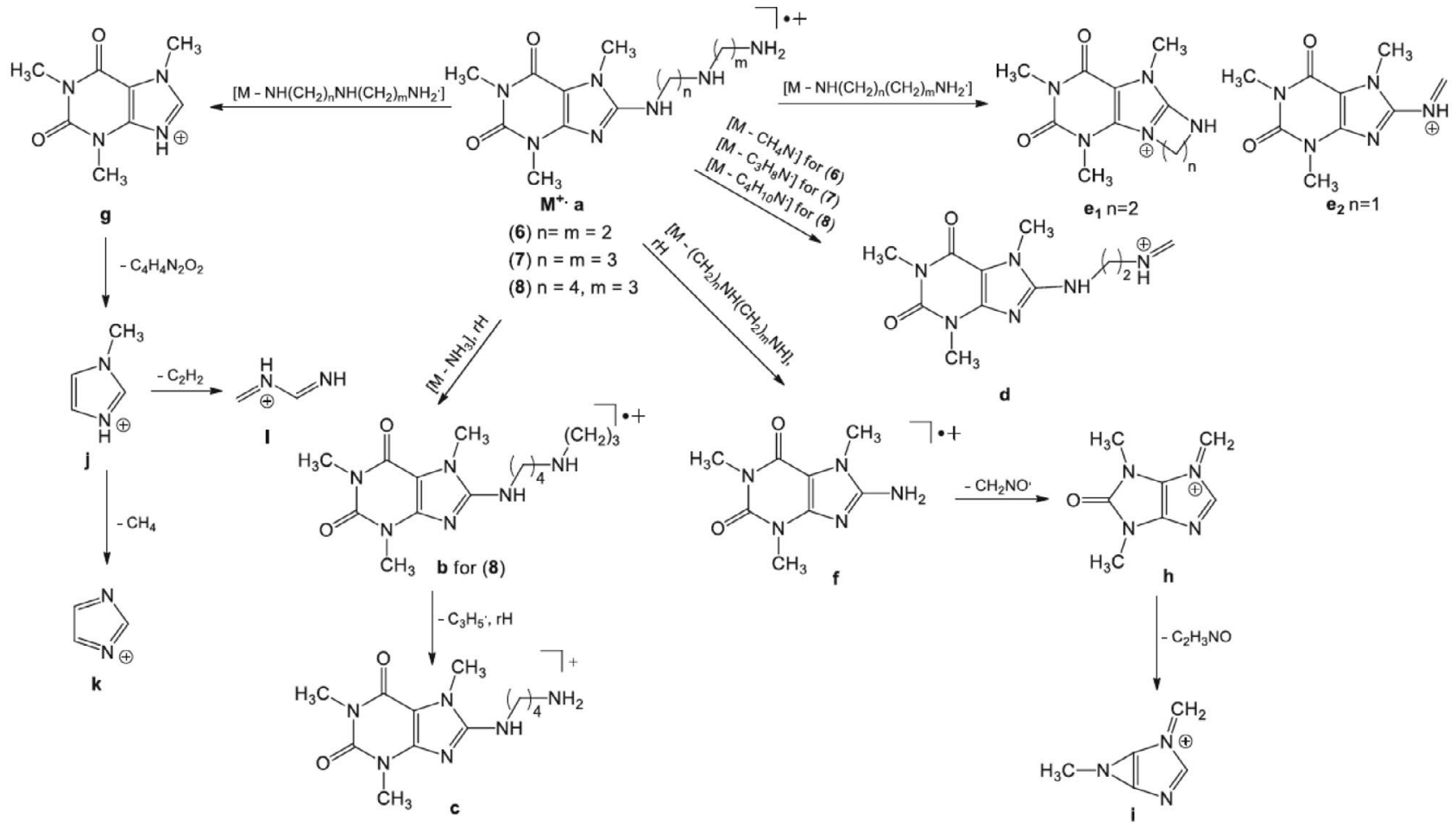

Sheme 2. The EI fragmentation pathways of compounds (6-8). 
spective molecular ions by the loss of two possible radicals $\mathrm{C}_{3} \mathrm{H}_{8} \mathrm{~N}^{\cdot}$ or $\mathrm{H}_{2} \mathrm{~N}^{\cdot}$ for 8-(5-aminopentylamino)caffeine (4) as well as $\mathrm{C}_{5} \mathrm{H}_{12} \mathrm{~N}^{\cdot}$ and $\mathrm{C}_{4} \mathrm{H}_{10} \mathrm{~N}^{\cdot}$ for 8-(6-aminohexylamino)caffeine (5), respectively.

The principal EI-MS fragmentation routes of 8-(3(3-(3-aminopropylamino)propylamino)propylamino)caf

Table 2. The EI MS data of 8-(2-(2-aminoethylamino)ethylamino) caffeine (6), 8-(3-(3-aminopropylamino)propylamino)caffeine (7) and 8-(4-(3-aminopropylamino)-butylamino)-caffeine (8).

\begin{tabular}{cccccc}
\hline Ion & $\boldsymbol{m} / \boldsymbol{z}$ & $\begin{array}{c}\text { Elemental } \\
\text { composition }\end{array}$ & \multicolumn{3}{c}{ \% Relative abundance } \\
& & $\mathbf{6}$ & $\mathbf{7}$ & $\mathbf{8}$ \\
\hline $\mathrm{M}^{+} \mathbf{a}$ & 337 & $\mathrm{C}_{15} \mathrm{H}_{27} \mathrm{~N}_{7} \mathrm{O}_{2}$ & - & - & 100 \\
& 323 & $\mathrm{C}_{14} \mathrm{H}_{25} \mathrm{~N}_{7} \mathrm{O}_{2}$ & - & 100 & - \\
& 295 & $\mathrm{C}_{12} \mathrm{H}_{21} \mathrm{~N}_{7} \mathrm{O}_{2}$ & 30 & - & - \\
$\mathbf{b}$ & 321 & $\mathrm{C}_{15} \mathrm{H}_{25} \mathrm{~N}_{6} \mathrm{O}_{2}$ & - & - & 10 \\
$\mathbf{c}$ & 280 & $\mathrm{C}_{12} \mathrm{H}_{20} \mathrm{~N}_{6} \mathrm{O}_{2}$ & - & - & 22 \\
$\mathbf{d}$ & 265 & $\mathrm{C}_{11} \mathrm{H}_{17} \mathrm{~N}_{6} \mathrm{O}_{2}$ & 100 & 2 & 3 \\
$\mathbf{e}_{\mathbf{1}}$ & 236 & $\mathrm{C}_{10} \mathrm{H}_{14} \mathrm{~N}_{5} \mathrm{O}_{2}$ & 12 & 63 & 56 \\
$\mathbf{e}_{\mathbf{2}}$ & 222 & $\mathrm{C}_{9} \mathrm{H}_{12} \mathrm{~N}_{5} \mathrm{O}_{2}$ & 43 & 29 & 60 \\
$\mathbf{f}$ & 209 & $\mathrm{C}_{8} \mathrm{H}_{11} \mathrm{~N}_{5} \mathrm{O}_{2}$ & 43 & 62 & 70 \\
$\mathbf{g}$ & 195 & $\mathrm{C}_{8} \mathrm{H}_{11} \mathrm{~N}_{4} \mathrm{O}_{2}$ & 10 & 16 & 16 \\
$\mathbf{h}$ & 165 & $\mathrm{C}_{7} \mathrm{H}_{9} \mathrm{~N}_{4} \mathrm{O}$ & 9 & 8 & 17 \\
$\mathbf{i}$ & 108 & $\mathrm{C}_{5} \mathrm{H}_{6} \mathrm{~N}_{3}$ & 3 & 5 & 7 \\
$\mathbf{j}$ & 83 & $\mathrm{C}_{4} \mathrm{H}_{7} \mathrm{~N}_{2}$ & 7 & 11 & 12 \\
$\mathbf{k}$ & 67 & $\mathrm{C}_{3} \mathrm{H}_{3} \mathrm{~N}_{2}$ & 16 & 27 & 24 \\
$\mathbf{l}$ & 57 & $\mathrm{C}_{2} \mathrm{H}_{5} \mathrm{~N}_{2}$ & 42 & 64 & 41 \\
\hline
\end{tabular}

feine (9) and 8-(3-(4-(3-aminopropylamino)butylamino) propylamino)caffeine (10) are interpreted as shown in Scheme 3 and Table 3 . The molecular ions a were observed with $81 \%$ and $100 \%$ relative abundances for 9 and $\mathbf{1 0}$, respectively. The elimination of radicals from the molecular ions a leads to the formation of even-electron bicyclic ions: $\mathbf{c}, \mathbf{g}$ and tricyclic ions: $\mathbf{e}, \mathbf{f}$. Ions $\mathbf{e}$ and $\mathbf{f}$ may be also formed from the odd-electron ion $\mathbf{b}$, which is created from the molecular ion a by elimination of the 1,3-propanediamine,

Table 3. The EI MS data of 8-(3-(3-(3-aminopropylamino)propylamino)propylamino)caffeine (9) and 8-(3-(4-(3-aminopropylamino)butylamino)propylamino)caffeine (10).

\begin{tabular}{|c|c|c|c|c|}
\hline \multirow[t]{2}{*}{ Ion } & \multirow[t]{2}{*}{$m / z$} & \multirow{2}{*}{$\begin{array}{c}\text { Elemental } \\
\text { composition }\end{array}$} & \multicolumn{2}{|c|}{ \% Relative abundance } \\
\hline & & & 9 & 10 \\
\hline \multirow[t]{2}{*}{$\mathrm{M}^{+\cdot} \mathbf{a}$} & 394 & $\mathrm{C}_{18} \mathrm{H}_{34} \mathrm{~N}_{8} \mathrm{O}_{2}$ & - & 81 \\
\hline & 380 & $\mathrm{C}_{17} \mathrm{H}_{32} \mathrm{~N}_{8} \mathrm{O}_{2}$ & 100 & - \\
\hline \multirow[t]{2}{*}{ b } & 321 & $\mathrm{C}_{15} \mathrm{H}_{25} \mathrm{~N}_{6} \mathrm{O}_{2}$ & - & 5 \\
\hline & 307 & $\mathrm{C}_{14} \mathrm{H}_{23} \mathrm{~N}_{6} \mathrm{O}_{2}$ & 2 & - \\
\hline c & 279 & $\mathrm{C}_{12} \mathrm{H}_{19} \mathrm{~N}_{6} \mathrm{O}_{2}$ & 15 & 9 \\
\hline d & 266 & $\mathrm{C}_{11} \mathrm{H}_{18} \mathrm{~N}_{6} \mathrm{O}_{2}$ & 63 & 3 \\
\hline $\mathbf{e}$ & 250 & $\mathrm{C}_{11} \mathrm{H}_{16} \mathrm{~N}_{5} \mathrm{O}_{2}$ & 20 & 22 \\
\hline f & 236 & $\mathrm{C}_{10} \mathrm{H}_{14} \mathrm{~N}_{5} \mathrm{O}_{2}$ & 52 & 43 \\
\hline $\mathbf{g}$ & 222 & $\mathrm{C}_{9} \mathrm{H}_{12} \mathrm{~N}_{5} \mathrm{O}_{2}$ & 35 & 23 \\
\hline h & 83 & $\mathrm{C}_{4} \mathrm{H}_{7} \mathrm{~N}_{2}$ & 8 & 100 \\
\hline $\mathbf{i}$ & 70 & $\mathrm{C}_{3} \mathrm{H}_{4} \mathrm{NO}$ & 40 & 50 \\
\hline $\mathbf{j}$ & 57 & $\mathrm{C}_{2} \mathrm{H}_{5} \mathrm{~N}_{2}$ & 68 & 78 \\
\hline
\end{tabular}<smiles>Cn1c(=O)c2c(nc(NCN[NH3+])n2C)n(C)c1=O</smiles><smiles>CN1CC1=O</smiles><smiles></smiles>

h<smiles>c1ccc2ccccc2c1</smiles>

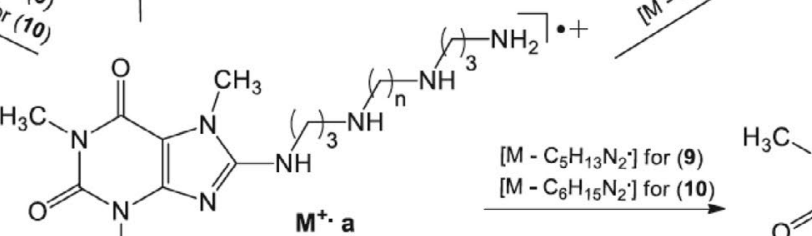

j IM- $-\mathrm{C}_{15} \mathrm{H}_{27} \mathrm{~N}_{6} \mathrm{O}_{2}$ ] for (9) $\left[\mathrm{M}-\mathrm{C}_{16} \mathrm{H}_{29} \mathrm{~N}_{6} \mathrm{O}_{2}^{\prime}\right]$ for (10)

$\left[\mathrm{M}-\mathrm{C}_{14} \mathrm{H}_{27} \mathrm{~N}_{7} \mathrm{O} \cdot\right]$ for $(9)$ $\left[\mathrm{M}-\mathrm{C}_{15} \mathrm{H}_{29} \mathrm{~N}_{7} \mathrm{O}\right.$ ] for (10)

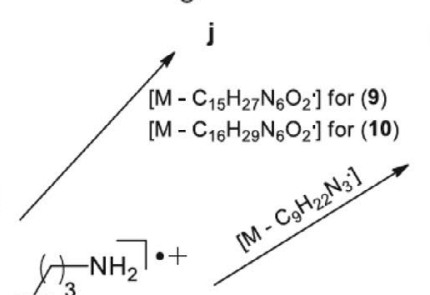<smiles>C=Nc1nc2c(c(=O)n(C)c(=O)n2C)n1C</smiles>

$\left[\mathrm{M}-\mathrm{C}_{5} \mathrm{H}_{13} \mathrm{~N}_{2} \cdot\right]$ for $(9)$ $\left[\mathrm{M}-\mathrm{C}_{6} \mathrm{H}_{15} \mathrm{~N}_{2}\right]$ for $(10)$<smiles></smiles><smiles>C1CCCC1</smiles>

(10) $n=4$

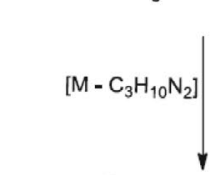<smiles></smiles>

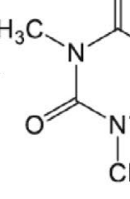<smiles>CCNNc1nc2c(c(=O)n(C)n2C)n1C</smiles>

(9) $n=1$

(10) $n=2$

Sheme 3. The EI fragmentation pathways of compounds (9-10). 
but can also be generated from the molecular ion by elimination of adequate radicals (Scheme 3). The ion $\mathbf{e}$ is also formed from the even-electron ion $\mathbf{c}$ by the elimination of methanimine.

The stability of new caffeine derivatives in gas phase was determined by theoretical method. Heats of formation of odd-electron ions of 8-alkylaminoderivatives were calculated. PM5 semiempirical calculations were performed using the Win-Mopac 2003 program. ${ }^{19-21}$ The final heats of formation (HOF) for odd-electron ions of all compounds are presented in Table 4.

Table 4. Heats of formation of odd-electron ions of polyamine derivatives of caffeine (1-10) calculated by PM5 semiempirical method.

\begin{tabular}{ccc}
\hline Ion & Heat of formation $[\mathrm{kcal} / \mathbf{m o l}]$ & $\Delta \mathbf{H O F}[\mathbf{k c a l} / \mathbf{m o l}]$ \\
\hline caffeine & -38.7572 & - \\
$\mathbf{1}$ & -41.3927 & -2.6355 \\
$\mathbf{2}$ & -47.3927 & -8.6355 \\
$\mathbf{3}$ & -53.0808 & -14.3236 \\
$\mathbf{4}$ & -58.6238 & -19.8666 \\
$\mathbf{5}$ & -64.3931 & -25.6359 \\
$\mathbf{6}$ & -39.3269 & -0.5697 \\
$\mathbf{7}$ & -50.4467 & -11.6895 \\
$\mathbf{8}$ & -56.4314 & -17.6742 \\
$\mathbf{9}$ & -51.3852 & -12.6280 \\
$\mathbf{1 0}$ & -57.7629 & -19.0057 \\
\hline
\end{tabular}

$\triangle \mathrm{HOF}=\mathrm{HOF}$ (odd-electron ion of 1-10) - HOF (odd-electron ion of caffeine)

As follows from the results, the odd-eletron ions of caffeine derivatives in the gas phase (under the experimental conditions similar to those in EI measurements) are stable. The lowest values of HOF from series 1-5 are observed for odd-electron ion of 8-(6-aminohexylamino) caffeine (5). Simultaneously, an increase of the length of an alkyl chain also reduces HOF. A similar relationship can be observed for odd-electron ions of compounds 6-8 as well as $\mathbf{9}$ and $\mathbf{1 0 .}$

PM5 semiempirical method is a reliable method for visualization of the structures in the gas phase. Calculated structures of odd-electron ions of: 8-(6-aminohexylamino)caffeine (5), 8-(4-(3-aminopropylamino)butylamino) caffeine (8), and 8-(3-(3-(3-aminopropylamino)propylamino)propylamino)caffeine (9) are presented in Figure 2.

\section{Conclusions}

The present study has demonstrated that the best method of mass spectrometric analysis of new polyamine derivatives of caffeine is the analysis of their EI mass spectra. Considering the length of the alkyl chain at $\mathrm{C}(8)$ position of caffeine molecule, the EI fragmentation pathways of compounds 1-10 were divided into three groups. The substitution of caffeine ring with alkylamino chain in position $\mathrm{C}(8)$ causes that the new pathway becomes more competitive than the primary fragmentation of unsubsituted caffeine with the elimination of a neutral molecule $\mathrm{CH}_{3}-\mathrm{N}=\mathrm{C}=\mathrm{O}$ from purine moiety. Such observation has not been noted previously in the literature in the cases of caffeine derivatives. According to PM5 semiempirical metod, the odd-electron ions of caffeine derivatives in gas phase (under the experimental conditions similar to those in EI measurement) are stable. Moreover, an increase in alkyl chain length at $\mathrm{C}(8)$ position of caffeine molecule reduces the values of HOF.

\section{References}

1. E. Fattorusso and O. Taglialatela-Scafati (Ed.), "Modern Alkaloids: Structure, Isolation, Synthesis, and Biology", WileyVCH, Weinheim, Germany, 2007, p. 3.

DOI:10.1002/9783527621071

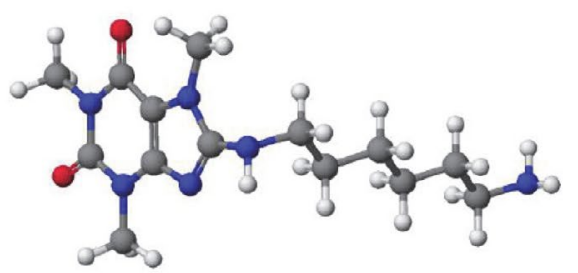

(5)

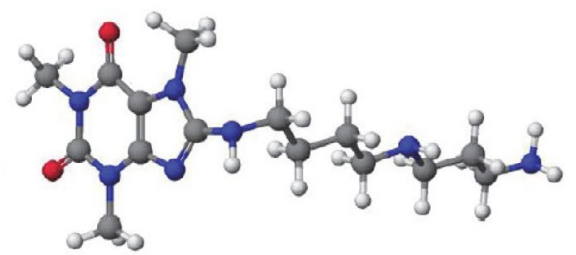

(8)

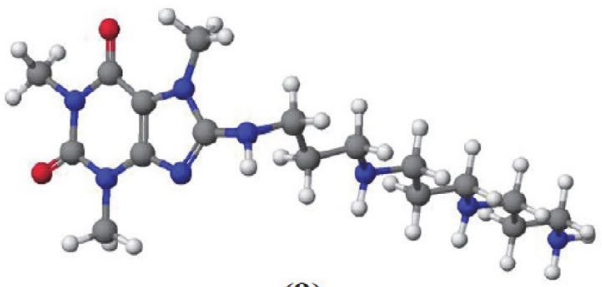

(9)

Figure 2. The optimized structures of odd-electron ion of compound $\mathbf{5 , 8}$ and $\mathbf{9}$. 
2. K. Ramalakshmi, L. Jagan Mohan Rao, Y. Takano-Ishikawa and M. Goto, Food Chem. 2009, 115, 79-85.

DOI:10.1016/j.foodchem.2008.11.063

3. S. Rivara, G. Piersanti, F. Bartoccini, G. Diamantini, D. Pala, T. Riccioni, M. A. Stasi, W. Cabri, F. Borsini, M. Mor, G. Tarzia and P. Minetti, , J. Med. Chem., 2013, 56, 1247-1261 DOI:10.1021/jm301686s

4. S. K. Srivastava and V. B. Singh, Spectrochim. Acta, Part A, 2013, 115, 45-50. DOI:10.1016/j.saa.2013.06.005

5. Y.-F. Chu, Y. Chen, P. H. Brown, B. J. Lyle, R. M. Black, I. H. Cheng, B. Ou and R. L. Prior, Food Chem., 2012, 131, 564568. DOI:10.1016/j.foodchem.2011.09.024

6. J. Bravo, L. Arbillaga, M. Paz de Pena and C. Cid, Food Chem. Toxicol. 2013, 60, 397-403. DOI:10.1016/j.fct.2013.08.002

7. I. L. Martins, J. P. Miranda, N. G. Oliveira, A. S. Fernand es, S. Gonçalves and A. M. M. Antunes, Molecules 2013, 18, 5251-5264. DOI:10.3390/molecules18055251

8. S. Miwa, S. Yano, Y. Tome, N. Sugimoto, Y. Hiroshima, F. Uehara, S. Mii, H. Kimura, K. Hayashi, E. V. Efimova, T. Fujiwara, H. Tsuchiya and R. M. Hoffman, , J. Cell. Biochem. 2013, 114, 2454-2460. DOI:10.1002/jcb.24593

9. H. P. Booysen, C. Moraal, G. Terre'Blanche, A. Petzer, J. J. Bergh and J. P. Petzer, Bioorg. Med. Chem., 2011, 19, 75077518. DOI:10.1016/j.bmc.2011.10.036

10. M. Bortolato, K. Chen and J. C. Shih, Adv. Drug Deliviery Rev., 2008, 60, 1527-1533. DOI:10.1016/j.addr.2008.06.002

11. R. V. Kalla, E. Elzein, T. Perry, X. Li, V. Palle, V. Varkhedkar, A. Gimbel, T. Maa, D. Zeng and J. Zabłocki, J. Med. Chem., 2006, 49, 3682-3692. DOI:10.1021/jm051268+
12. B. Jasiewicz, A. Sierakowska, N. Wandyszewska, B. Warżajtis, U. Rychlewska, R. Wawrzyniak and L. Mrówczyńska, Bioorg. Med. Chem. Lett., 2016, 26, 3994-3998.

DOI:10.1016/j.bmcl.2016.06.091

13. C. E. Kientz, A. G. Hulst, A. L. De Jong and E. R. J. Wils, Anal. Chem., 1996, 68, 675-681. DOI:10.1021/ac950892z

14. A. Bogo, P. G. Mantle, Phytochem. 2000, 54, 937-939. DOI:10.1016/S0031-9422(00)00169-2

15. J. L. Venzie, J. Castro, M. V. Balarama Krishna, D. M. Nelson and R. K. Marcus, Anal. Bioanal. Chem., 2007, 387, 321-333. DOI:10.1007/s00216-006-0934-Z

16. V. Feyer, O. Plekan, R. Richter, M. Coreno and K. C. Prince, Chem. Phys., 2009, 358, 33-39.

DOI:10.1016/j.chemphys.2008.12.014

17. S. Dagan, A. Amirav and T. Fujü, Int. J. Mass. Spectrom. Ion Proccesses, 1995, 15, 159-165.

DOI:10.1016/0168-1176(95)04321-7

18. B. Jasiewicz, A. Sierakowska, W. Jankowski, M. Hoffman, W. Piorońska, A. Górnicka, A. Bielawska , K. Bielawski, L. Mrówczyńska, Free Radical Res., 2018, 52(6), 724-738 DOI:10.1080/10715762.2018.1467561

19. CAChe 5.04, UserGuide, Fujitsu. 2003

20. J. J. P. Stewart, J. Comput. Chem. 10, 1989, 209-220. DOI: $10.1002 /$ jcc. 540100208

21. J. J. P. Stewart, "Optimization of Parameters for Semiempirical Methods II. Applications", J. Comput. Chem. 10, 1989, 221-264. DOI:10.1002/jcc.540100209

\section{Povzetek}

Raziskovali smo masno-spektrometrično fragmentacijo desetih novih 8-alkilamino derivatov kofeina. Na osnovi nizkoin visokoločljivostnih EI (elektronska ionizacija) masnih spektrov razpravljamo o poteku fragmentacije novih poliaminskih derivatov kofeina. Pri novih spojinah nismo opazili klasične fragmentacije purinskega skeleta, povezane z eliminacijo nevtralne molekule $\mathrm{CH}_{3} \mathrm{~N}(1) \mathrm{C}(2) \mathrm{O}$ iz molekulskega iona. Vendar pa smo opazili nov, zanimiv potek fragmentacije opisanih derivatov kofeina. Izračunali smo tudi entalpijo nastanka ion-radikalov 8-alkilaminokofeinskih derivatov. 